\title{
Estimation of soybean leaf wetness from meteorological variables
}

\author{
Wagner Teigi Igarashi(1), Marcelo Augusto de Aguiar e Silva(1), \\ José Alexandre de França(2), Seiji Igarashi(1) and Otávio Jorge Grigoli Abi Saab(1)
}

(1)Universidade Estadual de Londrina, Departamento de Agronomia, Rodovia Celso Garcia Cid, PR 445, Km 380, Campus Universitário, Caixa Postal 10.011, CEP 86057-970 Londrina, PR, Brazil. E-mail: wigarashi@gmail.com, aguiaresilva@uel.br, seigarashi@gmail.com, abisaab@uel.br (2)Universidade Estadual de Londrina, Departamento de Engenharia Elétrica, Rodovia Celso Garcia Cid, PR 445, Km 380, Campus Universitário, Caixa Postal 10.011, CEP 86057-970 Londrina, PR, Brazil. E-mail: franca@la2i.com

\begin{abstract}
The objective of this work was to determine models for the estimation of leaf wetness percentage at three heights in the soybean (Glycine max) canopy, using meteorological variables from stations installed at the crop site and at an agrometeorological station. The experiment was conducted in three harvest seasons, in an area cropped with soybean, in the municipality of Londrina, in the state of Paraná, Brazil. To collect the meteorological variables, electronic trees were installed at four heights $(0.3,0.6,0.9$, and $1.7 \mathrm{~m})$ in the crop and a station was installed in an agrometeorological station. The data were separated according to days with and without rain, and the analyses of correlation and of simple and multiple regressions were carried out, in order to obtain models with equations for leaf wetness estimation. Most of the equations that did not use the data of the sensors installed at $1.7 \mathrm{~m}$, especially those of the models based on variables only from the agrometeorological station, presented low reliability. The models obtained with meteorological data only from the soybean crop show high reliability and use a lower amount of variables, which makes them a good alternative for wetness estimation.
\end{abstract}

Index terms: Glycine max, empirical models, leaf wetness sensors, percentage of leaf wetness.

\section{Estimativa do molhamento foliar da soja a partir de variáveis meteorológicas}

\begin{abstract}
Resumo - O objetivo deste trabalho foi determinar modelos para estimativa da percentagem de molhamento foliar em três alturas no dossel da soja (Glycine max), a partir de variáveis meteorológicas de estações instaladas na cultura e em posto agrometeorológico. O experimento foi conduzido em três safras agrícolas, em área com cultura de soja, no Município de Londrina, PR. Para a coleta das variáveis meteorológicas, foram instaladas árvores eletrônicas com sensores de molhamento, em quatro alturas $(0,3,0,6,0,9$ e 1,7 m), na cultura e uma estação em posto agrometeorológico. Separaram-se os dados de dias com e sem chuva, e realizaram-se as análises de correlação e de regressões simples e múltipla, para obter modelos com equações de estimativa de molhamento. A maioria das equações que não utilizou os dados dos sensores instalados a 1,7 m, principalmente as dos modelos baseados apenas nas variáveis do posto agrometeorológico, apresentou baixa confiabilidade. Os modelos obtidos a partir de dados meteorológicos unicamente da cultura de soja apresentam alta confiabilidade e utilizam menor quantidade de variáveis, o que os torna boa alternativa para estimativa de molhamento.
\end{abstract}

Termos para indexação: Glycine max, modelos empíricos, sensores de molhamento foliar, percentagem de molhamento foliar.

\section{Introduction}

Asian rust (Phakopsora pachyrhizi Sid. \& P. Sid.) is a fungal disease of great relevance to soybean [Glycine max (L.) Merr.] crops (Godoy et al., 2016). In Brazil, it is important due to its fast large-scale dissemination and to the severe damages it causes, resulting in linear yield losses of up to $80 \%$ (Silva et al., 2015). Because of the difficulty in identifying initial soybean rust symptoms, chemical control is applied on a scheduled program by most growers (Godoy, 2009), disregarding other aspects that determine the need or not of spraying. Creative Commons Attribution 4.0 International License
Asian rust intensity on crops depends on several factors, including agrometeorological variables, which affect all fungus biological processes. Among these factors, Vale et al. (2004) highlight leaf wetness measured as leaf wetness duration (LWD), which is a requirement for the occurrence of infection processes and fungi reproduction. According to Igarashi et al. (2014), another method used to quantify leaf wetness is leaf wetness percentage (LWP). These authors pointed out that LWP is important, since, in days when wetting takes place for a long period, but in 
low proportions, LWD may be overestimated and misinterpreted. Leaf wetness quantification by LWP can aid in the development of applicable and reliable disease predictions; however, most known studies still adopt LWD-based models.

LWD has been used to measure leaf wetness in Asian rust prediction models, such as the one proposed by Reis et al. (2004) and tested by Igarashi et al. (2016). However, sensors to measure leaf wetness are not available in most weather stations and, many times, require careful operation; if not operated correctly, there may be significant data collection errors (Almeida \& Machado, 2009; Durigon \& J. Van Lier, 2013).

Analytical and empirical models for leaf wetness estimation can be an alternative to Asian rust prediction models. Analytical models, also known as physical ones, are more complex and need several entry variables, making their use difficult, while empirical models use meteorological variables and statistical models to estimate leaf wetness, requiring fewer variables (Kim et al., 2010).

Hamada et al. (2008) and Alvares et al. (2015) developed empirical models for wetness estimation at the state and national levels, in order to aid in disease control in crops and commercial forests. However, regarding decision-making for disease control, sitespecific models better represent local conditions. Taking this into account, empirical models can be used to estimate leaf wetness with good precision, mainly when calculated with meteorological variables measured on-site and compared with real leaf wetness for reliability check (Kim et al., 2002; Sentelhas et al., 2004a, 2008; Beruski et al., 2015). It should be noted that the use of empirical models for leaf wetness estimation, with easily obtained meteorological variables, can also be implemented in more complex Asian rust prediction models.

The objective of this work was to determine models for the estimation of leaf wetness percentage at three heights in the soybean canopy, using meteorological variables from stations installed at the crop site and at an agrometeorological station.

\section{Materials and Methods}

The study was conducted during three harvest seasons (2011/2012, 2012/2013, and 2013/2014) in an experimental area in the municipality of Londrina, in the state of Paraná, Brazil $\left(23^{\circ} 34^{\prime} 23^{\prime \prime} \mathrm{S}, 51^{\circ} 21^{\prime} 24^{\prime \prime} \mathrm{W}\right.$, at an altitude of $560 \mathrm{~m}$ ), on a Latossolo Vermelho eutroférrico (Santos et al., 2013), i.e., an Eutrorthox. According to Köppen's classification, the climate of the region is of the Cfa type, with an average annual air temperature of $21.1^{\circ} \mathrm{C}$ and an average accumulated annual rainfall of 1,635 mm (IAPAR, 2016).

The cultivar BMX Potência RR, recommended for growing regions in northern Paraná, was used for soybean cultivation, which was preceded by a wheat (Triticum aestivum L.) crop under a no-tillage system in the experimental area. In all crop seasons, seeding took place during the period recommended for the cultivar, with line spacing of $0.45 \mathrm{~m}, 19$ plants per linear meter, and base fertilization with $300 \mathrm{~kg} \mathrm{ha}^{-1} \mathrm{~N}-\mathrm{P}_{2} \mathrm{O}_{5^{-}}$ $\mathrm{K}_{2} \mathrm{O}$ (0-20-20) fertilizer. Plant stages were evaluated based on the soybean phenological scale (Fehr \& Caviness, 1977). When necessary, the experiment adopted the cultural treatments and phytosanitary controls recommended for the crop (Sediyama, 2016).

When soybean was between the V6 and V8 stages, four electronic wetting trees (EWTs) were installed, 20 $\mathrm{m}$ apart in order not to interfere in data collection. Each EWT has 16 electronic leaf wetness sensors to measure wetness period duration and LWP, distributed at four heights in the soybean canopy $(0.3,0.6,0.9$, and $1.7 \mathrm{~m})$, besides one temperature and air relative humidity sensor, kept at $1.7 \mathrm{~m}$ in a meteorological shelter. The wetness sensors received two coats of latex paint and thermal treatment (Sentelhas, 2004b) and were placed at an angle of $45^{\circ}$.

The WMR200A Professional Weather Station Center (Oregon Scientific, Inc., Tualatin, OR, USA) was installed in an agrometeorological station 50 $\mathrm{m}$ north of the experimental area. That station has temperature, relative air humidity, and wind direction and speed sensors, as well as an udomograph.

The following independent variables were used in the models: average air relative humidity (\%), average air temperature $\left({ }^{\circ} \mathrm{C}\right)$, and LWP $(\%)$, all obtained at the height of $1.7 \mathrm{~m}$ in the soybean crop; and average air relative humidity $(\%)$, average air temperature $\left({ }^{\circ} \mathrm{C}\right)$, minimum average air temperature $\left({ }^{\circ} \mathrm{C}\right)$, average wind speed $\left(\mathrm{km} \mathrm{h}^{-1}\right)$, and maximum wind speed $\left(\mathrm{km} \mathrm{h}^{-1}\right)$, all at the height of $1.7 \mathrm{~m}$ at the agrometeorological station.

The evaluated variables were measured automatically, every $5 \mathrm{~min}$, during the R1 and R6 soybean phenological stages, when there was greater 
canopy closure. Collected data were transformed into mean per hour and separated according to days with and without rain, to distinguish leaf wetness due to rain or dew. The experiment used a total of 1,920 data per hour for days without rain and 1,764 data per hour for days with rain.

The collected variables were analyzed using: the coefficient of correlation obtained through the correlation analysis; the coefficient of determination $\left(\mathrm{R}^{2}\right)$ and adjusted $\mathrm{R}^{2}$; and the results of Fisher's F-test, through simple and multiple linear regressions to detect the presence or not of a correlation. The F-test was used to identify statistical models that could estimate LWP at $0.3,0.6$, and $0.9 \mathrm{~m}$ in the soybean crop based on climate variables.

The stepwise backward method was used to determine the number of explanatory variables to be considered during the adjustment of the multiple regression model. Therefore, only significant variables were used in the equations. For the leaf wetness estimation models, the used variables were obtained: both at the agrometeorological station and at the crop site, for models 1 and 2 for dry days, and 7 and 8 for rainy days; only at the meteorological station, for models 3 and 4 for dry days, and 9 and 10 for rainy days; and only at the crop site, for models 5 and 6 for dry days, and 11 and 12 for rainy days (Tables 1 and 2).

Equations with $\mathrm{R}^{2}$ higher or equal to 0.8 , at $5 \%$ probability, were considered of high reliability because the variables used in the equations were significant by the Pearson correlation analysis, with p-value below $2.2 \times 10^{-16}$. The $\mathrm{R}^{2}$ allows determining how much of the data variation is explained by the model and how much is due to residue. The p-value helps to determine the significance level of the obtained result, since the lower the p-value, the greater is the evidence of existing differences and of the adequacy of the model.

For tabulation, as well as descriptive and exploratory analyses, the Excel and the R software, version 3.0.2, with the R-commander package (R Core Team, 2013), were used.

\section{Results and Discussion}

The equations obtained for models 1, 2, 5, and 6, used to estimate leaf wetness for dry days, showed $\mathrm{R}^{2}$ above 0.8 , at $5 \%$ probability (Table 1 ), and, consequently, high reliability. The exception were equations 3 from model 1 and 16 from model 6, which showed a lower $\mathrm{R}^{2}$ value. The equations generated for models 3 and

Table 1. Leaf wetness estimation models obtained using variables from both the agrometeorological station and the soybean (Glycine max) crop site (models 1 and 2), only from the agrometeorogical station (models 3 and 4), and only from the crop site (models 5 and 6) for dry days during the 2011/2012, 2012/2013, and 2013/2014 harvest seasons.

\begin{tabular}{|c|c|c|c|}
\hline Model & Multiple linear regression equations ${ }^{(1)}$ & $\mathrm{R}^{2}$ & p-value \\
\hline \multirow{3}{*}{1} & $1 \mathrm{LWP}(0.3 \mathrm{~m})=127.54954-6.24579 \mathrm{X} 2+2.96710 \mathrm{X} 3+1.33636 \mathrm{X} 4-1.37747 \mathrm{X} 5-1.59242 \mathrm{X} 7$ & 0.83 & $<0.0001$ \\
\hline & $2 \operatorname{LWP}(0.6 \mathrm{~m})=147.91539-6.98593 \mathrm{X} 2+3.32035 \mathrm{X} 3+1.47015 \mathrm{X} 4-1.57807 \mathrm{X} 5-2.13025 \mathrm{X} 7$ & 0.84 & $<0.0001$ \\
\hline & $3 \operatorname{LWP}(0.9 \mathrm{~m})=177.17620-8.00164 \mathrm{X} 2+3.81110 \mathrm{X} 3+1.47731 \mathrm{X} 4-1.89404 \mathrm{X} 5+0.68229 \mathrm{X} 6-1.83347 \mathrm{X} 7$ & 0.79 & $<0.0001$ \\
\hline \multirow{3}{*}{2} & 4 LWP $(0.3 \mathrm{~m})=47.98549-2.61945 \mathrm{X} 2+1.11239 \mathrm{X} 3+0.61727 \mathrm{X} 4-0.40517 \mathrm{X} 5-0.99359 \mathrm{X} 7+0.53482 \mathrm{X} 8$ & 0.88 & $<0.0001$ \\
\hline & $5 \mathrm{LWP}(0.6 \mathrm{~m})=50.13201-2.52919 \mathrm{X} 2+1.04093 \mathrm{X} 3+0.58639 \mathrm{X} 4-0.38313 \mathrm{X} 5-1.39430 \mathrm{X} 7+0.65728 \mathrm{X} 8$ & 0.90 & $<0.0001$ \\
\hline & $6 \operatorname{LWP}(0.9 \mathrm{~m})=38.31986-1.60554 \mathrm{X} 2+0.54198 \mathrm{X} 3+0.21463 \mathrm{X} 4-0.19071 \mathrm{X} 5+0.25791 \mathrm{X} 6-1.14043 \mathrm{X} 7+0.93820 \mathrm{X} 8$ & 0.94 & $<0.0001$ \\
\hline \multirow{3}{*}{3} & 7 LWP $(0.3 \mathrm{~m})=67.10633-5.39906 \mathrm{X} 1+3.27491 \mathrm{X} 3+0.41065 \mathrm{X} 4-1.67444 \mathrm{X} 7$ & 0.78 & $<0.0001$ \\
\hline & $8 \mathrm{LWP}(0.6 \mathrm{~m})=79.23311-6.06410 \mathrm{X} 1+3.69005 \mathrm{X} 3+0.40955 \mathrm{X} 4-2.22394 \mathrm{X} 7$ & 0.79 & $<0.0001$ \\
\hline & $9 \operatorname{LWP}(0.9 \mathrm{~m})=9621120-7.04302 \mathrm{X} 1+4.33005 \mathrm{X} 3+0.20289 \mathrm{X} 4+0.67379 \mathrm{X} 6-1.9488 \mathrm{X} 7$ & 0.71 & $<0.0001$ \\
\hline \multirow{3}{*}{4} & $10 \mathrm{LWP}(0.3 \mathrm{~m})=42.30313-1.79715 \mathrm{X} 3+0.57961 \mathrm{X} 4-1.56077 \mathrm{X} 7$ & 0.77 & $<0.0001$ \\
\hline & $11 \mathrm{LWP}(0.6 \mathrm{~m})=51.37474-2.00677 \mathrm{X} 3+0.59932 \mathrm{X} 4-2.09627 \mathrm{X} 7$ & 0.77 & $<0.0001$ \\
\hline & $12 \operatorname{LWP}(0.9 \mathrm{~m})=65.24187-2.26839 \mathrm{X} 3+0.41771 \mathrm{X} 4-1.86773 \mathrm{X} 7$ & 0.69 & $<0.0001$ \\
\hline \multirow{3}{*}{5} & 13 LWP $(0.3 \mathrm{~m})=21.95868-1.38547 \mathrm{X} 2+0.34909 \mathrm{X} 5+0.72227 \mathrm{X} 8$ & 0.86 & $<0.0001$ \\
\hline & $14 \operatorname{LWP}(0.6 \mathrm{~m})=16.44007-1.27356 \mathrm{X} 2+0.37750 \mathrm{X} 5+0.86804 \mathrm{X} 8$ & 0.87 & $<0.0001$ \\
\hline & $15 \operatorname{LWP}(0.9 \mathrm{~m})=19.27378-0.88018 \mathrm{X} 2+0.11950 \mathrm{X} 5+1.04020 \mathrm{X} 8$ & 0.93 & $<0.0001$ \\
\hline \multirow{3}{*}{6} & $16 \mathrm{LWP}(0.3 \mathrm{~m})=8.10063+1.07836 \mathrm{X} 8$ & 0.77 & $<0.0001$ \\
\hline & $17 \mathrm{LWP}(0.6 \mathrm{~m})=7.58987+1.21806 \mathrm{X} 8$ & 0.81 & $<0.0001$ \\
\hline & $18 \operatorname{LWP}(0.9 \mathrm{~m})=3.444349+1.225426 \mathrm{X} 8$ & 0.91 & $<0.0001$ \\
\hline
\end{tabular}

${ }^{(1)} \mathrm{LWP}$, leaf wetness percentage; X1, average air temperature at the agrometeorogical station; X2, air temperature at the crop site; X3, air minimum temperature at the agrometeorological station; X4, air relative humidity at the meteorological station; X5, air relative humidity at the crop site; X6, maximum wind at the meteorological station; X7, average wind at the agrometeorological station; and $\mathrm{X} 8$, leaf wetness percentage at $1.7 \mathrm{~m}$ in the crop site. 
4 using data from the agrometeorological station also showed $\mathrm{R}^{2}$ below 0.8 and low reliability to estimate leaf wetness percentage.

The equations from models 8,11 , and 12 , used to estimate leaf wetness for rainy days, showed $\mathrm{R}^{2}$ above 0.8 , at $5 \%$ probability, except equation 34 from model 12 , with $\mathrm{R}^{2}$ of 0.73 (Table 2). The equations from models 7, 9, and 10 had $\mathrm{R}^{2}$ below 0.8 , and, therefore, showed low reliability to estimate leaf wetness.

The equations from models $1,3,4,7,9$, and 10 for dry and rainy days did not use LWP data obtained at $1.7 \mathrm{~m}$ in the soybean crop. Most of these equations showed $\mathrm{R}^{2}$ below 0.8 , except equations 1 and 2 from model 1, which represented the heights of 0.3 and 0.6 $\mathrm{m}$. In models 3, 4, 9 and 10, the variables air minimum and average temperature, air relative humidity, and average and maximum wind speed were only collected at the agrometeorological station and all showed $\mathrm{R}^{2}$ below 0.8 . This shows that these models do not have good reliability to estimate leaf wetness when just variables from the agrometeorological station are used. Costa et al. (2015) obtained $\mathrm{R}^{2}$ values above 0.8 only when they associated, in the equation, data on external radiation to that on internal and external temperature measured at $1.5 \mathrm{~m}$ height. In the present study, $\mathrm{R}^{2}$ was greater in the equations for the lower and middle thirds of the plant, i.e., at 0.3 and $0.6 \mathrm{~m}$, respectively, in the models that did not use LWP data obtained at $1.7 \mathrm{~m}$. This shows that the variables used to produce these equations represent better the microclimate of the soybean canopy than the environment exposed to the atmosphere at $0.9 \mathrm{~m}$, where the effect of a greater number of variables is observed.

The use of LWP data at $1.7 \mathrm{~m}$ in models 2, 5, 6, 8, 11 , and 12 for dry and rainy days caused the $\mathrm{R}^{2}$ value to increase above 0.8 in most equations, except in equations 16 and 34, in models 6 and 12, at the height of $0.3 \mathrm{~m}$. These results show that using LWP data at $1.7 \mathrm{~m}$ helps to obtain equations with high reliability. Beruski et al. (2015) and Costa et al. (2015) also found that the estimation models showed better performance when variables measured directly at the studied site were used.

In the present study, models 5 and 11 are the most adequate because their equations show high reliability at all heights, at 5\% probability, using data obtained from the EWTs installed in the crop site, where air temperature and relative humidity and leaf wetness percentage data were collected at $1.7 \mathrm{~m}$. Models 6 and 12 also showed equations, obtained by simple linear

Table 2. Leaf wetness estimation models obtained using variables from both the agrometeorological station and the soybean (Glycine max) crop site (models 7 and 8), only from the agrometeorogical station (models 9 and 10), and only from the crop site (models 11 and 12) for rainy days during the 2011/2012, 2012/2013, and 2013/2014 harvest seasons.

\begin{tabular}{|c|c|c|c|}
\hline Model & Multiple linear regression equations ${ }^{(1)}$ & $\mathrm{R}^{2}$ & p-value \\
\hline \multirow{3}{*}{7} & 19 LWP $(0.3 \mathrm{~m})=51.52725-4.41955 \mathrm{X} 2+1.42553 \mathrm{X} 3+0.91607 \mathrm{X} 4-0.15259 \mathrm{X} 5+1.08750 \mathrm{X} 6-2.27106 \mathrm{X} 7$ & 0.74 & $<0.0001$ \\
\hline & $20 \operatorname{LWP}(0.6 \mathrm{~m})=80.24948-6.08890 \mathrm{X} 2+2.50053 \mathrm{X} 3+1.27673 \mathrm{X} 4-0.66172 \mathrm{X} 5+1.31052 \mathrm{X} 6-2.80992 \mathrm{X} 7$ & 0.78 & $<0.0001$ \\
\hline & $21 \mathrm{LWP}(0.9 \mathrm{~m})=106.44939-6.79510 \mathrm{X} 2+2.90822 \mathrm{X} 3+1.18250 \mathrm{X} 4-0.90987 \mathrm{X} 5+1.41759 \mathrm{X} 6-2.76769 \mathrm{X} 7$ & 0.72 & $<0.0001$ \\
\hline \multirow{3}{*}{8} & $22 \mathrm{LWP}(0.3 \mathrm{~m})=10.26596-1.38294 \mathrm{X} 2+0.34842 \mathrm{X} 4+0.25685 \mathrm{X} 5+0.45553 \mathrm{X} 6-1.02902 \mathrm{X} 7$ & 0.82 & $<0.0001$ \\
\hline & $23 \operatorname{LWP}(0.6 \mathrm{~m})=25.06817+0.86709 \mathrm{X} 1-2.37630 \mathrm{X} 2+0.58684 \mathrm{X} 4-0.15772 \mathrm{X} 5+0.45321 \mathrm{X} 6-1.16008 \mathrm{X} 7$ & 0.88 & $<0.0001$ \\
\hline & $24 \operatorname{LWP}(0.9 \mathrm{~m})=40.39236-1.90715 \mathrm{X} 2+0.60264 \mathrm{X} 3+0.26998 \mathrm{X} 4-0.25216 \mathrm{X} 5+0.40093 \mathrm{X} 6-0.77167 \mathrm{X} 7$ & 0.91 & $<0.0001$ \\
\hline \multirow{3}{*}{9} & 25 LWP $(0.3 \mathrm{~m})=30.37948-2.17291 \mathrm{X} 1+0.84028 \mathrm{X} 4+0.81604 \mathrm{X} 6-1.99454 \mathrm{X} 7$ & 0.72 & $<0.0001$ \\
\hline & $26 \operatorname{LWP}(0.6 \mathrm{~m})=15.28498-2.04430 \mathrm{X} 1+1.02122 \mathrm{X} 4+0.87211 \mathrm{X} 6-2.37127 \mathrm{X} 7$ & 0.74 & $<0.0001$ \\
\hline & $27 \mathrm{LWP}(0.9 \mathrm{~m})=26.0749-3.9827 \mathrm{X} 1+1.9503 \mathrm{X} 3+0.7892 \mathrm{X} 4+1.0743 \mathrm{X} 6-2.4524 \mathrm{X} 7$ & 0.67 & $<0.0001$ \\
\hline \multirow{3}{*}{10} & $28 \operatorname{LWP}(0.3 \mathrm{~m})=27.24802-2.17615 \mathrm{X} 3+0.88124 \mathrm{X} 4-1.00303 \mathrm{X} 7$ & 0.72 & $<0.0001$ \\
\hline & $29 \operatorname{LWP}(0.6 \mathrm{~m})=9.0681-1.9626 \mathrm{X} 3+1.0776 \mathrm{X} 4-1.3087 \mathrm{X} 7$ & 0.74 & $<0.0001$ \\
\hline & $30 \operatorname{LWP}(0.9 \mathrm{~m})=12.95904-1.88796 \mathrm{X} 3+0.90155 \mathrm{X} 4-1.15320 \mathrm{X} 7$ & 0.66 & $<0.0001$ \\
\hline \multirow{3}{*}{11} & $31 \mathrm{LWP}(0.3 \mathrm{~m})=27.46739-1.87760 \mathrm{X} 2+0.47607 \mathrm{X} 5+0.62322 \mathrm{X} 8$ & 0.81 & $<0.0001$ \\
\hline & $32 \operatorname{LWP}(0.6 \mathrm{~m})=57.17362-2.32626 \mathrm{X} 2+0.19541 \mathrm{X} 5+0.81299 \mathrm{X} 8$ & 0.86 & $<0.0001$ \\
\hline & $33 \operatorname{LWP}(0.9 \mathrm{~m})=55.90168-1.69465 \mathrm{X} 2-0.09315 \mathrm{X} 5+0.92460 \mathrm{X} 8$ & 0.91 & $<0.0001$ \\
\hline \multirow{3}{*}{12} & $34 \operatorname{LWP}(0.3 \mathrm{~m})=14.48372+0.96282 \mathrm{X} 8$ & 0.73 & $<0.0001$ \\
\hline & $35 \operatorname{LWP}(0.6 \mathrm{~m})=11.12872+1.12187 \mathrm{X} 8$ & 0.82 & $<0.0001$ \\
\hline & $36 \operatorname{LWP}(0.9 \mathrm{~m})=4.46975+1.08283 \mathrm{X} 8$ & 0.89 & $<0.0001$ \\
\hline
\end{tabular}

${ }^{(1)}$ LWP, leaf wetness percentage; X1, average air temperature at the agrometeorogical station; X2, air temperature at the crop site; X3, air minimum temperature at the agrometeorological station; X4, air relative humidity at the meteorological station; X5, air relative humidity at the crop site; X6, maximum wind at the meteorological station; X7, average wind at the agrometeorological station; and $\mathrm{X} 8$, leaf wetness percentage at $1.7 \mathrm{~m}$ in the crop site. 
regression, with high reliability at the heights of 0.6 and $0.9 \mathrm{~m}$, with the use of LWP data at $1.7 \mathrm{~m}$. This model is an alternative to the one based on number of hours with relative humidity above $90 \%$, for which the obtained results are contradictory, according to Gleason et al. (1994). However, models 6 and 12 must be tested in other sites for generalizations.

The equations generated with data from dry days have greater applicability than those from rainy days, because dew is a physical phenomenon that is difficult to be quantified, since it depends on several interactions (Sentelhas et al., 2008). However, rainfall can be easily visualized and quantified, and may represent leaf wetness on the whole plant. According to Schmitz \& Grant (2009), rain causes immediate leaf wetness, which is longer than that of dew, and is the predominant source of water for the inferior third of the soybean crop, where dew wetness is lower. The authors pointed out that dew events disseminate P. pachyrhizi uredospores from the medium third to the superior third of the plant more easily when the inoculum is present in the area.

The equations obtained for rainy days showed lower coefficients of determination than those for dry days and, therefore, less reliability. Sentelhas et al. (2004a) reported that, both in the analytical and empirical models, there is lower efficiency during rainy days, especially with high wind speed. Another possible explanation, according to Schmitz \& Grant (2009), for the low reliability of these models is that wetness events during the day are more variable due to heating by sunlight and possible plant drying immediately after rainfall.

It should be highlighted that it may be necessary to install meteorological stations with leaf wetness sensors at the height of $1.7 \mathrm{~m}$ in the crop site. Sensors installed at a fixed position allow adjusting wetness estimation values by empirical coefficients in more than one height inside the crop canopy, as described by Sentelhas et al. (2004a). The use of LWP data at $1.7 \mathrm{~m}$ increased $\mathrm{R}^{2}$ mainly in the upper third of the plant at $0.9 \mathrm{~m}$, followed by the middle and lower thirds; this sensor better represents dry and rainy days, since it is installed in an environment exposed to the atmosphere.

Asian rust is a disease with great severity in the middle and lower thirds of the soybean plant (Zambenedetti et al., 2007; Cunha \& Peres, 2010; Garcés-Fiallos \& Forcelini, 2013). Therefore, models that estimate wetness at the height of 0.6 and $0.3 \mathrm{~m}$ are more adequate, showing greater applicability in the management of the disease, which is currently the most important for the crop.

\section{Conclusions}

1. Models with meteorological variables obtained only at the height of $1.7 \mathrm{~m}$ in the soybean (Glycine max) crop show high reliability and use less variables in their equations, which makes them a good alternative for leaf wetness estimation.

2. The joint adoption of all variables from the agrometeorological station and soybean crop site allows obtaining wetness estimation models with high reliability for days with and without rain at the three soybean canopy heights $(0.3,0.6$, and $0.9 \mathrm{~m})$ evaluated.

3. Models that use variables obtained only at the agrometeorological station for days with and without rain do not provide equations with high reliability for the three tested canopy heights.

\section{Acknowledgments}

To Coordenação de Aperfeiçoamento de Pessoal de Nível Superior (Capes), for doctoral scholarship granted to the first author.

\section{References}

ALMEIDA, H.A. de; MACHADO, R.C.R. Estimativa da duração do período de molhamento por orvalho em um ecossistema cacau. Revista Brasileira de Engenharia Agrícola e Ambiental, v.13, p.724-728, 2009. DOI: 10.1590/S1415-43662009000600009.

ALVARES, C.A.; MATTOS, E.M. de; SENTELHAS, P.C.; MIRANDA, A.C.; STAPE, J.L. Modeling temporal and spatial variability of leaf wetness duration in Brazil. Theoretical and Applied Climatology, v.120, p.455-467, 2015. DOI: 10.1007/ s00704-014-1182-3.

BERUSKI, G.C.; PEREIRA, A.B.; SENTELHAS, P.C. Desempenho de diferentes modelos de estimativa da radiação solar global em Ponta Grossa, PR. Revista Brasileira de Meteorologia, v.30, p.205-213, 2015. DOI: 10.1590/0102-778620130097.

COSTA, J. de O.; ALMEIDA, A.N. de; COELHO, R.D.; FOLEGATTI, M.V.; JOSÉ, J.V. Modelo de estimativa de elementos micrometeorológicos em ambiente protegido. Water Resources and Irrigation Management, v.4, p.25-31, 2015. DOI: 10.19149/2316-6886/wrim.v4n1-3p25-31.

CUNHA, J.P.A.R. da; PERES, T.C.M. Influência de pontas de pulverização e adjuvante no controle químico da ferrugem 
asiática da soja. Acta Scientiarum. Agronomy, v.32, p.597-602, 2010. DOI: 10.4025/actasciagron.v32i4.2502.

DURIGON, A.; J. VAN LIER, Q. de. Duração do período de molhamento foliar: medição e estimativa em feijão sob diferentes tratamentos hídricos. Revista Brasileira de Engenharia Agrícola e Ambiental, v.17, p.200-207, 2013. DOI: 10.1590/ S1415-43662013000200011.

FEHR, W.R.; CAVINESS, C.E. Stages of soybean development. Ames: Iowa State University of Science ant Technology, 1977. 11p. (Special Report, 80).

GARCÉS-FIALLOS, F.R.; FORCELINI, C.A. Controle comparativo da ferrugem asiática da soja com fungicida triazol ou mistura de triazol + estrobilurina. Bioscience Journal, v.29, p.805-815, 2013.

GLEASON, M.L.; TAYLOR, S.E.; LOUGHIN, T.M.; KOEHLER, K.J. Development and validation of an empirical model to estimate the duration of dew periods. Plant Disease, v.78, p.1011-1016, 1994. DOI: 10.1094/PD-78-1011.

GODOY, C.V.; FLAUSINO, A.M.; SANTOS, L.C.M.; DEL PONTE, E.M. Eficiência do controle da ferrugem asiática da soja em função do momento de aplicação sob condições de epidemia em Londrina, PR. Tropical Plant Pathology, v.34, p.56-61, 2009. DOI: $10.1590 /$ S1982-56762009000100011.

GODOY, C.V.; SEIXAS, C.D.S.; SOARES, R.M.; MARCELINOGUIMARÃES, F.C.; MEYER, M.C.; COSTAMILAN, L.M. Asian soybean rust in Brazil: past, present, and future. Pesquisa Agropecuária Brasileira, v.51, p.407-421, 2016. DOI: 10.1590/ S0100-204X2016000500002.

HAMADA, E.; GHINI, R.; FERNANDES, J.L.; PEDRO JÚNIOR, M.J.; ROSSI, P. Spatial and temporal variability of leaf wetness duration in the State of São Paulo, Brazil. Scientia Agricola, v.65, p.26-31, 2008. Special issue. DOI: 10.1590/S010390162008000700006.

IAPAR. Instituto Agronômico do Paraná. Médias históricas em estações do Paraná. 2016. Available at: <http://www.iapar. br/arquivos/Image/monitoramento/Medias_Historicas/Londrina. htm>. Accessed on: June 182017.

IGARASHI, W.T.; FRANÇA, J.A. de; SILVA, M.A. de A. e; IGARASHI, S.; ABI SAAB, O.J.G. Application of prediction models of asian soybean rust in two crop seasons, in Londrina, PR. Semina: Ciências Agrárias, v.37, p.2881-2890, 2016. DOI: 10.5433/1679-0359.2016v37n5p2881.

IGARASHI, W.T.; SILVA, M.A. de A. e; IGARASHI, S.; ABI SAAB, O.J.G.; FRANÇA, J.A. de. Duração e porcentagem de molhamento foliar determinados pelo espaçamento entrelinhas, e influência sobre a ferrugem asiática da soja. Summa Phytopathologica, v.40, p.123-127, 2014. DOI: 10.1590/01005405/1969.

KIM, K.S.; TAYLOR, S.E.; GLEASON, M.L.; KOEHLER, K.J. Model to enhance site-specific estimation of leaf wetness duration. Plant Disease, v.86, p.179-185, 2002. DOI: 10.1094/ PDIS.2002.86.2.179.
KIM, K.S.; TAYLOR, S.E.; GLEASON, M.L.; NUTTER JR., F.W.; COOP, L.B.; PFENDER, W.F.; SEEM, R.C.; SENTELHAS, P.C.; GILLESPIE, T.J.; DALLA MARTA, A.; ORLANDINI, S. Spatial portability of numerical models of leaf wetness duration based on empirical approaches. Agricultural and Forest Meteorology, v.150, p.871-880, 2010. DOI: 10.1016/j. agrformet.2010.02.006.

R CORE TEAM. R: A language and environment for statistical computing. Vienna: R Foundation for Statistical Computing, 2013. Available at: <http://www.R-project.org/>. Accessed on: Feb. 172017.

REIS, E.M.; SARTORI, A.F.; CAMARA, R.K. Modelo climático para a previsão da ferrugem da soja. Summa Phytopathologica, v.30, p.290-292, 2004.

SANTOS, H.G. dos; JACOMINE, P.K.T.; ANJOS, L.H.C. dos; OLIVEIRA, V.A. de; LUMBRERAS, J.F.; COELHO, M.R.; ALMEIDA, J.A. de; CUNHA, T.J.F.; OLIVEIRA, J.B. de. Sistema brasileiro de classificação de solos. 3.ed. rev. e ampl. Brasília: Embrapa, 2013. 353p.

SCHMITZ, H.F.; GRANT, R.H. Precipitation and dew in a soybean canopy: spatial variations in leaf wetness and implications for Phakopsora pachyrhizi infection. Agricultural and Forest Meteorology, v.149, p.1621-1627, 2009. DOI: 10.1016/j. agrformet.2009.05.001.

SEDIYAMA, T. (Ed.). Produtividade da soja. Londrina: Mecenas, 2016. 310p.

SENTELHAS, P.C.; DALLA MARTA, A.; ORLANDINI, S.; SANTOS, E.A.; GILLESPIE, T.J.; GLEASON, M.L. Suitability of relative humidity as an estimator of leaf wetness duration. Agricultural and Forest Meteorology, v.148, p.392-400, 2008. DOI: 10.1016/j.agrformet.2007.09.011.

SENTELHAS, P.C.; GILlESPIE, T.J.; MONTEIRO, J.E.B. de A.; ROWLANDSON, T. Estimating leaf wetness duration on a cotton crop from meteorological data. Revista Brasileira de Agrometeorologia, v.12, p.235-245, 2004a.

SENTELHAS, P.C.; MONTEIRO, J.E.B.A.; GILLESPIE, T.J. Electronic leaf wetness duration sensor: why it should be painted. International Journal of Biometeorology, v.48, p.202-205, 2004b. DOI: 10.1007/s00484-004-0200-z.

SILVA, A.F. da; SEDIYAMA, T.; SILVA, F.C. dos S.; BEZERRA, A.R.G.; ROSA, D.P.; CRUZ, C.D.; DIAS, L.A. dos S. Effect of defoliation from the bottom to the top on the yield of Brazilian soybean cultivars. African Journal of Agricultural Research, v.10, p.3296-3304, 2015. DOI: 10.5897/AJAR2015.9938.

VALE, F.X.R. do; JESUS JÚNIOR, W.C. de; ZAMBOLIM, L. (Ed.). Epidemiologia aplicada ao manejo de doenças de plantas. Belo Horizonte: Perfil, 2004. 532p.

ZAMBENEDETTI MAGNANI, E.B.; ALVES, E.; ARAÚJO, D.V. Eventos dos processos de pré-penetração, penetração e colonização de Phakopsora pachyrhizi em folíolos de soja. Fitopatologia Brasileira, v.32, p.156-160, 2007. DOI: 10.1590/ S0100-41582007000200011.

$\overline{\text { Received on July 4, } 2017 \text { and accepted on December 19, } 2017}$ 